\title{
Synthesis and Magnetic Properties of Sr- Substituted M-type Ba Hexaferrite Nanoparticles
}

\author{
A. M. EL-Refai \\ Physics Department, Faculty of women for Art, Science and Education, \\ Ain Shams University, Cairo, Egypt.
}

Barium hexaferrites with the general formula $\mathrm{Ba}_{1-x} \mathrm{Sr}_{x} \mathrm{Fe}_{12} \mathrm{O}_{19}(x=0.1,0.3$, $0.5,0.7,0.8,0.9)$ were synthesized by the citrate method and annealed at $1100^{\circ} \mathrm{C}$ for 2 hours. The structural and magnetic characteristics were studied by X-ray diffraction (XRD), scanning electron microscopy (SEM), and vibrating sample magnetometer (VSM) techniques. XRD patterns confirmed the formation of BaSr-M phase in addition to the non-ferromagnetic intermediate phase $\left(\alpha-\mathrm{Fe}_{2} \mathrm{O}_{3}\right)$. The magnetic properties such as saturation magnetization $\left(M_{s}\right)$, remanence $\left(M_{r}\right)$, squarness ratio $\left(M_{r} / M_{s}\right)$ and coercivity $\left(H_{c}\right)$ were calculated from hysteresis loops. The magnetic properties of the Ba-ferrite were remarkably modified due to the substitution of $\mathrm{Sr}$, this suggests that the materials under investigation are suitable for different applications requiring high temperatures.

\section{Introduction}

Hexagonal ferrites are ferrimagnetic materials, their magnetic properties depends on their crystalline structure. Nanoparticles have attracted much attention in fundamental sciences and technological applications due to their novel and /or enhanced physicochemical properties [1]. M-type hexaferrites $\mathrm{Ba}(\mathrm{Sr}) \mathrm{Fe}_{12} \quad \mathrm{O}_{19}$ have been extensively studied for application in magnetic recording and microwave devices due to their high values of coercivity, saturation magnetization, Curie temperature, in addition to their excellent chemical stability, resistance of corrosion, and low cost [2-4]. Barium ferrites are prepared using various synthesis routes like citrate precursor [5], sol-gel process[6,7], chemical co-precipitation [8], hydrothermal synthesis[9], conventional solid state calcination route[10], spray pyrolysis[11] and molten salt synthesis[12], etc.

The magnetic properties of M-type hexaferrite can be modified by different methods, one of these methods is the ion or cation substitution technique which is used to improve the performance of the M-type hexaferrite. Researchers have modified and improved the properties of M-ferrites by 
substituting non-magnetic ions $\left(\mathrm{Ba}^{2+}\right)$ with $\mathrm{Sr}^{2+} / \mathrm{La}^{2+} / \mathrm{Pb}^{2+}$ ions [7,13)] or substituting $\mathrm{Fe}^{3+}$ ions by trivalent $\mathrm{Al}^{3+}, \mathrm{Ga}^{3+}, \mathrm{Mn}^{3+}$ ions $[\mathbf{1 4 , 1 5}]$ or with both type of dopant divalent cations $\left(\mathrm{Zn}^{2+}, \mathrm{Co}^{2+}, \mathrm{Mg}^{2+}, \mathrm{Zr}^{2+}\right.$,etc.) and tetravalent cations $\left(\mathrm{Ti}^{4+}, \mathrm{Sn}^{4+}, \mathrm{Ir}^{4+}\right.$,etc.) [16-19] to tailor these properties. In all these cases the substituted ions must have ionic radii close to that of the original ones and also conserve the electrical neutrality.

In hexagonal ferrite structure, magnetization is related to the magnetic distribution of $\mathrm{Fe}^{3+}$ ions on five crystallographic sites i.e. the $12 \mathrm{k}-2 \mathrm{a}-2 \mathrm{~b}$ (spinup) and $4 \mathrm{f}_{1}-4 \mathrm{f}_{2}$ (spin-down) [20]. The $\mathrm{Fe}^{3+}$ ions positioned at different sites make different contributions to the magnetic properties of the hexaferrites. It is strongly dependent on the super- exchange interaction strengths $\left(\mathrm{Fe}^{3+}-\mathrm{O}-\mathrm{Fe}^{3+}\right)$, therefore the magnetization reduces with the substitution of $\mathrm{Fe}^{3+}$ ions in the spin-up state and increases with substitution in spin-down state. It has been reported that the substitution of $\mathrm{Co}-\mathrm{Ru}$ and $\mathrm{Ce}-\mathrm{Ni}$ can improve the magnetic properties of $\mathrm{Sr}-\mathrm{Ba} \mathrm{M}$ - hexaferrite [21,22]. Shirtcliffe et al. [23] studied aluminium doped $\mathrm{Ba}(\mathrm{Sr})$ hexaferrite nanoparticles $\mathrm{Ba}(\mathrm{Sr}) \mathrm{Al}_{\mathrm{x}} \mathrm{Fe}_{12-\mathrm{x}} \mathrm{O}_{19}$ prepared by auto-combustion method and they found that it was possible to replace half of the iron in $\mathrm{Ba}$ ferrites and all of it in $\mathrm{Sr}$ ferrites with $\mathrm{Al}$, retaining the ferrite structure. The size of these nanoparticles is smaller than the size of single domain $(1 \mu \mathrm{m})$ and may be of technical use as they move from iron to aluminium ferrites and they may be promising for imaging applications. Liu et al.[24] found that the magnetic properties of Co substituted $\mathrm{Sr}$ hexaferrite $\left(\mathrm{SrFe}_{12-\mathrm{x}} \mathrm{Co}_{\mathrm{x}} \mathrm{O}_{19}\right)$ were modified and there was a dependence of the magnetooptical Kerr effect on Co substitution, a noticeable Kerr activity was obtained in case of $\mathrm{x}=0.2$. $\mathrm{Xu}$ et al.[25] synthesized $\mathrm{BaFe}_{12} \mathrm{O}_{19}$ nanoparticles from different $\mathrm{Fe} / \mathrm{Ba}$ ratios by reverse micelle technique. Pure barium ferrite phase and best magnetic properties could be obtained for the sample prepared from $\mathrm{Fe} / \mathrm{Ba}$ ratio of 11 , the existence of $\alpha-\mathrm{Fe}_{2} \mathrm{O}_{3}$ in other materials decreases the magnetic properties. In the present paper, the effect of substitution of $\mathrm{Sr}$ on the structural and magnetic properties of $\mathrm{Ba}_{1-\mathrm{x}} \mathrm{Sr}_{\mathrm{x}} \mathrm{Fe}_{12} \mathrm{O}_{19}$ samples synthesized by citrate method were studied.

\section{Experimental Method}

Nanosized $\mathrm{Sr}_{\mathrm{x}} \mathrm{Ba}_{1-\mathrm{x}} \mathrm{Fe}_{12} \mathrm{O}_{19} ; 0.1 \leq \mathrm{x} \leq 0.9$ were synthesized via citrate precursor method [26]. Stoichiometric amounts of ferric, barium and strotium nitrates were mixed with a molar ratio of $\mathrm{Fe}^{3+}$ to $\left(\mathrm{Ba}^{2+} / \mathrm{Sr}^{2+}\right)$ of $12: 1$, dissolved in de-ionized water and stirred for $5 \mathrm{~min}$. The ratio of citric acid was adjusted to be $1: 1$ with respect to metal nitrates. The solution was stirred thoroughly to assure a uniform mixing. Ammonia and/or nitric acid were added to adjust the $\mathrm{pH}$ of the solution at 7 . The solution was heated using a hot plate. The 
precursor complex dehydrated and became more viscous with time producing a dark gel. The gel ignited giving a voluminous fluffy powder and a ceramic nano-oxide was obtained. The samples were annealed at $1100{ }^{\circ} \mathrm{C}$ for $4 \mathrm{~h}$.

Phase identification of the prepared samples was conducted on by an $\mathrm{X}$-ray diffractometer (Proker D8) using $\mathrm{Cu}-\mathrm{K} \alpha$ radiation source $(\lambda=1.5418 \AA$ ) $)$. The morphology of the samples were observed by scanning electron microscopy (JEOL JSM-5600LV). The magnetic properties were investigated at room temperature using a vibrating sample magnetometer (Lake Shore 7410) with an applied magnetic field up to $20 \mathrm{kOe}$. DC-magnetic susceptibility was carried out in the temperature range 300- $900 \mathrm{~K}$ using Faraday's method as a function of temperature and at different applied magnetic field intensities. The temperature of the samples was measured using K-type thermocouple. The accuracy of measuring temperature in the magnetic susceptibility measurement was $\pm 1^{\circ} \mathrm{C}$.

\section{Results and Discussion}

The XRD patterns of the samples $\mathrm{Ba}_{1-\mathrm{x}} \mathrm{Sr}_{\mathrm{X}} \mathrm{Fe}_{12} \mathrm{O}_{19} ; 0.1 \leq \mathrm{x} \leq 0.9$ calcined at $1100^{\circ} \mathrm{C}$ for 4 hours are shown in Fig.(1). The main diffraction peaks appeared in the XRD were indexed with the standard patterns for hexagonal ferrite $\mathrm{BaFe}_{12} \mathrm{O}_{19}$ (ICCD 04-008-0274) for $\mathrm{x}=0.1, \mathrm{Ba}_{0.5} \mathrm{Sr}_{0.5} \mathrm{Fe}_{12} \mathrm{O}_{19}$ (00-0511879) for $\mathrm{x}=0.3,0.5$ and finally $\mathrm{SrFe}_{12} \mathrm{O}_{19}$ (ICCD 04-006-3369) for $\mathrm{x}=0.7,0.8$, 0.9. The XRD patterns reveal the existence of some small peaks of secondary phase (the non-ferromagnetic intermediate phase) $\alpha-\mathrm{Fe}_{2} \mathrm{O}_{3}$ which was detected in all samples. The appearance of the non-ferromagnetic intermediate phase $\alpha$ $\mathrm{Fe}_{2} \mathrm{O}_{3}$ may be due to insufficient reaction temperature and time required to develop mono-crystalline phase[27]. It is noticed that the intensity of this phase increases with inceasing $\mathrm{Sr}^{2+} / \mathrm{Ba}^{2+}$ ratio as indicated by the relative intensities of the diffraction peaks. The lattice constants (a and c) were calculated on a hexagonal basis. The values of unit cell volume (V), the crystallite size (D) and $\mathrm{X}$-ray density $\left(\mathrm{d}_{\mathrm{x}}\right)$ were reported in Table[1]. The variation of lattice constants $\mathrm{a}$ and $\mathrm{c}$ against $\mathrm{Sr}$ content is shown in Fig. $(2 \mathrm{a}, \mathrm{b})$. The values of lattice constant $\mathrm{a}$ are slightly increasing while those of $\mathrm{c}$ are slightly decreasing with increasing of $\mathrm{Sr}$ content and this can be attributed to the smaller ionic radius of $\mathrm{Sr}^{2+}$ $(1.18 \AA \hat{)})$ as compared with that of $\mathrm{Ba}^{2+}(1.35 \AA \hat{)})$. It is obvious from Table[1] that the unit cell volume V decreases with increasing $\mathrm{Sr}$ content which is due to the decrease in the length of $\mathrm{c}$ axis. The dependence of X-ray density on $\mathrm{Sr}$ content is shown in Fig.(2c). It is clear from the figure that the X-ray density decreases with increasing Sr content owing to the smaller atomic mass of Sr (87.62 amu) as compared to that of $\mathrm{Ba}(137.33 \mathrm{amu})$, since the X-ray density is directly related to the molecular weight of the sample. The crystallite size (D) was calculated from Sherrer's formula $D=0.89 \lambda / \beta \cos \theta$, where $\lambda$ is the wave length 
of the $\mathrm{X}$-ray used, $\beta$ is the corrected full width at half maxima and $\theta$ is the corresponding Bragg angle. The values of crystallite size are given in Table[1]. The average values ranges from 90 to $218 \mathrm{~nm}$ depending strongly on $\mathrm{Sr}^{2+}$ content.
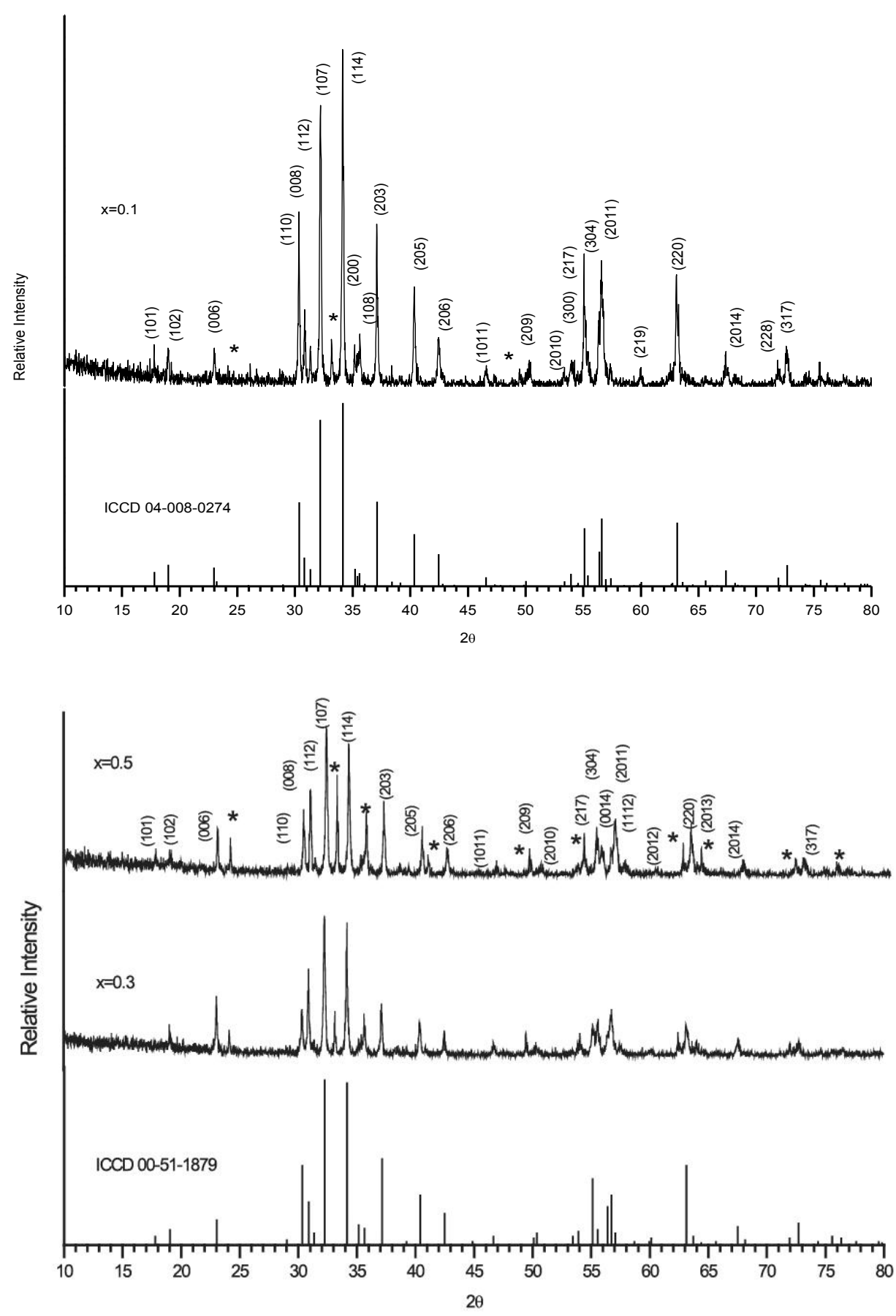


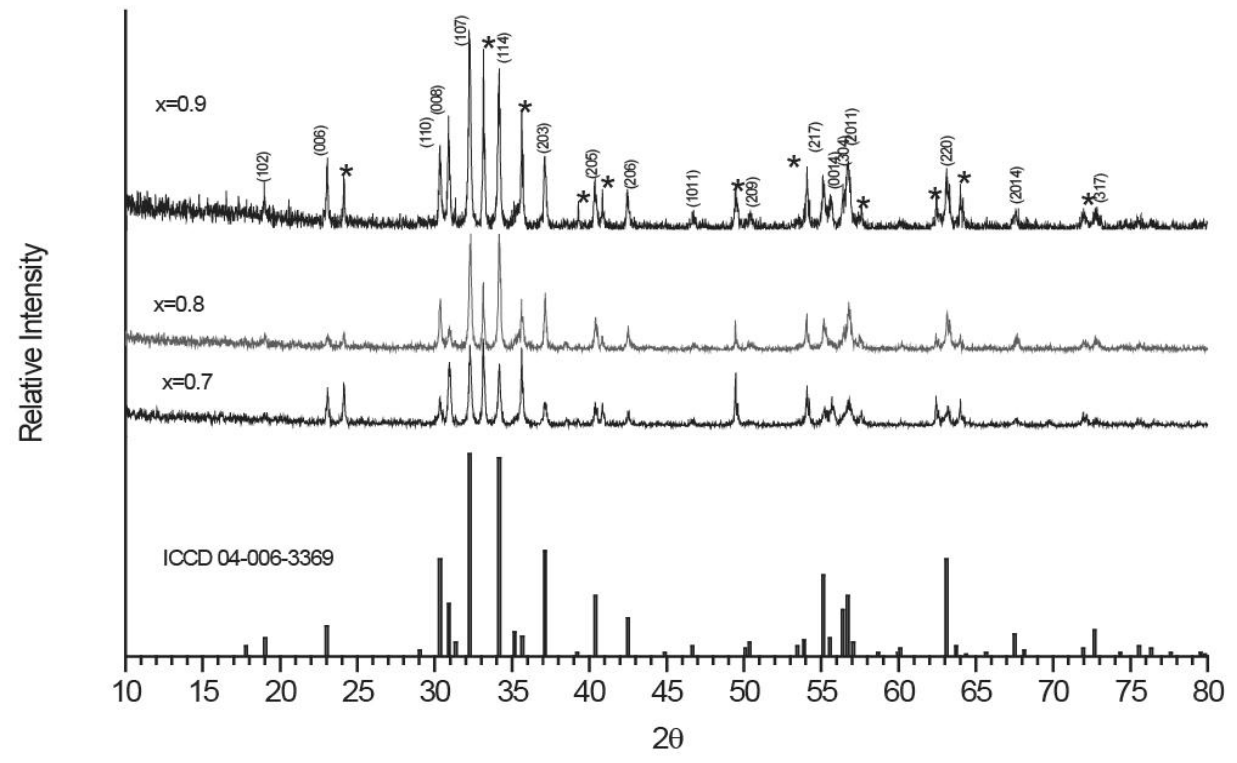

Fig.(1): $\mathrm{X}$-ray diffraction patterns of samples $\mathrm{Ba}_{1-\mathrm{x}} \mathrm{Sr}_{\mathrm{x}} \mathrm{Fe}_{12} \mathrm{O}_{19}$ annealed at $1100{ }^{\circ} \mathrm{C}$ for $4 \mathrm{~h}$.The peaks of hematite is indexed by here by $*$.

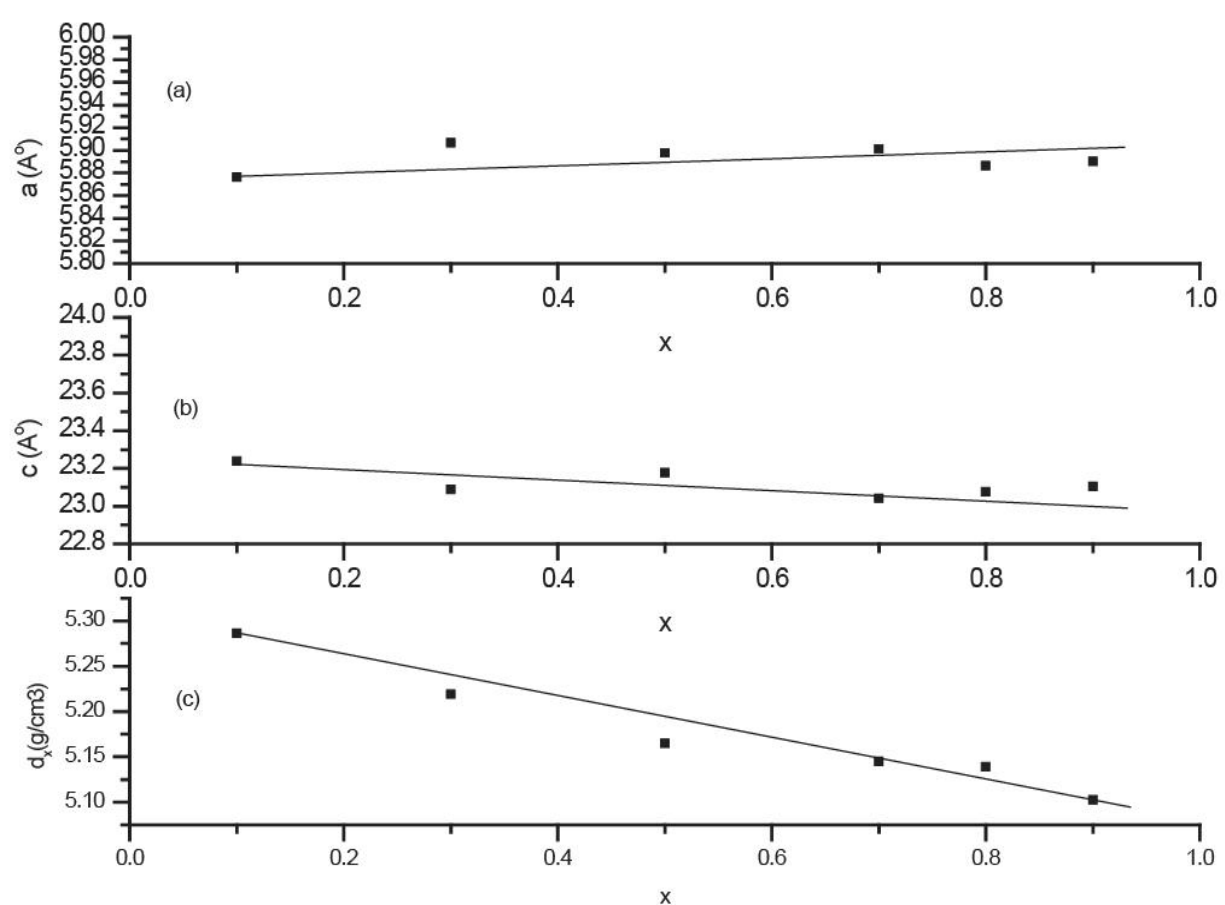

Fig.(2a-c): Lattice constants a,c and $x$-ray density $d_{x}$ of the samples as a function of the Sr content. 
Table (1): Lattice parameters (a,c), average crystallite size (D), unit cell volume $(\mathrm{V}), \mathrm{X}$-ray density $\left(\mathrm{d}_{\mathrm{x}}\right)$ of the sample $\mathrm{Ba}_{1-\mathrm{x}} \mathrm{Sr}_{\mathrm{x}} \mathrm{Fe}_{12} \mathrm{O}_{19}$.

\begin{tabular}{|l|r|r|r|r|l|}
\hline Sample & $\mathrm{a}(\AA)$ & $\mathrm{c}(\AA)$ & $\mathrm{V}\left(\AA^{3}\right)$ & $\mathrm{d}_{\mathrm{x}}\left(\mathrm{g} / \mathrm{cm}^{3}\right)$ & $\mathrm{Av} . \mathrm{D}(\mathrm{nm})$ \\
\hline $\mathrm{x}=0.1$ & 5.87633 & 23.2381 & 694.94 & 5.29 & 145 \\
\hline $\mathrm{x}=0.3$ & 5.90662 & 23.0877 & 697.60 & 5.22 & 218 \\
\hline $\mathrm{x}=0.5$ & 5.89774 & 23.1782 & 698.53 & 5.16 & 90 \\
\hline $\mathrm{x}=0.7$ & 5.90098 & 23.0418 & 694.88 & 5.14 & 163 \\
\hline $\mathrm{x}=0.8$ & 5.88618 & 23.0777 & 692.46 & 5.14 & 144 \\
\hline $\mathrm{x}=0.9$ & 5.89009 & 23.1046 & 694.18 & 5.10 & 167 \\
\hline
\end{tabular}

SEM micrographs of substituted Ba-M are shown in Fig.(3a-f). The large grains in the figure represent $\mathrm{Ba}-\mathrm{M}$ hexaferrite, while the small aggregates refer to $\alpha-\mathrm{Fe}_{2} \mathrm{O}_{3}$ particles. It is obvious from the figure that the secondary phase $\alpha-\mathrm{Fe}_{2} \mathrm{O}_{3}$ exists on the grain boundary. It can be noted that the grains have well defined shape and clear boundaries.

The room temperature $\mathrm{M}-\mathrm{H}$ loops for $\mathrm{Ba}_{1-\mathrm{x}} \mathrm{Sr}_{\mathrm{x}} \mathrm{Fe}_{12} \mathrm{O}_{19}(0.1 \leq \mathrm{x} \leq 0.9)$ are shown in Fig.4(a,b). Fig.(4a) represents the early saturated magnetization, low coericivity (narrow loop) while Fig.4(b) represents lack of saturation with high coercivity (wide loop) which is due to large magnetocrystalline anisotropy. The magnetic parameters such as saturation magnetization $\left(\mathrm{M}_{\mathrm{s}}\right)$, remanence $\left(\mathrm{M}_{\mathrm{r}}\right)$, squarness ratio $\left(\mathrm{M}_{\mathrm{r}} / \mathrm{M}_{\mathrm{s}}\right)$ and coercivity $\left(\mathrm{H}_{\mathrm{c}}\right)$ were depicted from hysteresis loops and have been shown in Table[2] and Fig.5(a-c). It was found that doping with $\mathrm{Sr}$ at $\mathrm{x}=0.1$ improved the magnetization as compared with the parent compound [28-35]. Increasing the concentration of $\mathrm{Sr}$ will decrease the magnetization because the secondary phase increases. As the $\mathrm{Sr}$ content increases at $\mathrm{x} \geq 0.5$, the difference in the magnetic parameters is mainly due to secondary phase. The existence of an appreciable amount of the non-magnetic intermediate phase $\alpha-\mathrm{Fe}_{2} \mathrm{O}_{3}$ and the interaction between these non-magnetic and magnetic particles affects the magnetic anisotropy and changes the magnetic properties of the samples [36] with respect to the pure phase $\mathrm{BaFe}_{12} \mathrm{O}_{19}$.

Table (2): Saturation magnetization (Ms), remnant magnetization (Mr), Coercivity (Hc) and Curie temperature (Tc) of $\mathrm{Ba}_{1-x} \mathrm{Sr}_{x} \mathrm{Fe}_{12} \mathrm{O}_{19}$ samples.

\begin{tabular}{|c|c|c|c|c|c|c|c|}
\hline Sample & $\mathrm{M}_{\mathrm{s}}(\mathrm{emu} / \mathrm{g})$ & $\mathrm{M}_{\mathrm{r}}(\mathrm{emu} / \mathrm{g})$ & $\mathrm{H}_{\mathrm{c}}(\mathrm{Oe})$ & $\mathrm{M}_{\mathrm{r}} / \mathrm{M}_{\mathrm{s}}$ & $\mathrm{T}_{\mathrm{c}}(\mathrm{K})$ & $\mu_{\mathrm{eff}}(\mathrm{BM})$ & $\Theta(\mathrm{K})$ \\
\hline $\mathrm{x}=0.1$ & 60.67 & 31.70 & 2922 & 0.52 & 696 & 9.78 & 654 \\
\hline $\mathrm{x}=0.3$ & 51.17 & 19.45 & 489 & 0.38 & 700 & 16.97 & 708 \\
\hline $\mathrm{x}=0.5$ & 52.63 & 23.07 & 521 & 0.44 & 643 & 10.81 & 637 \\
\hline $\mathrm{x}=0.7$ & 34.29 & 12.87 & 575 & 0.38 & 673 & 21.76 & 710 \\
\hline $\mathrm{x}=0.8$ & 51.41 & 31.03 & 1970 & 0.60 & 765 & 14.30 & 734 \\
\hline $\mathrm{x}=0.9$ & 46.80 & 16.80 & 460 & 0.36 & 828 & 13.91 & 812 \\
\hline
\end{tabular}




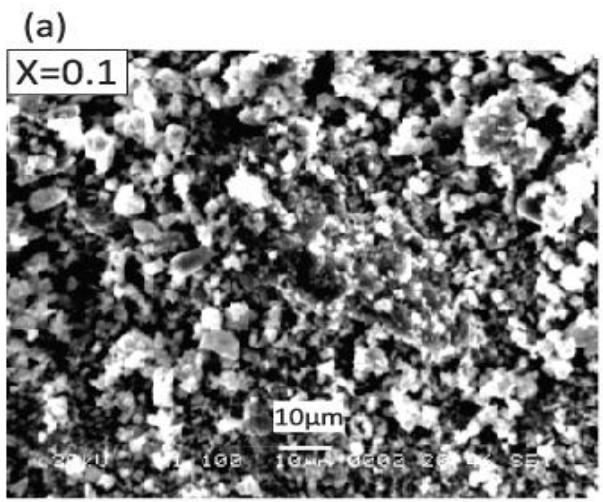

(c)

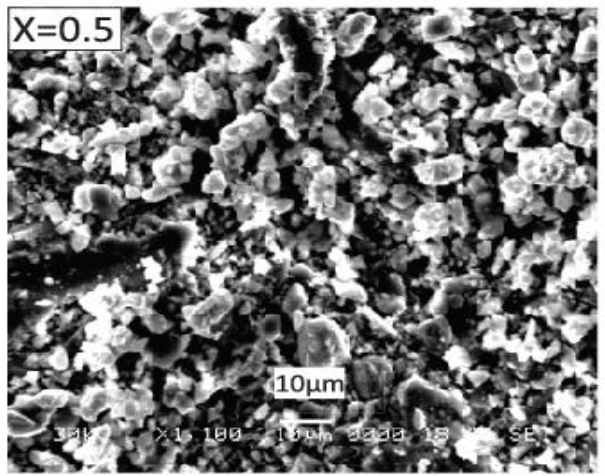

(b)

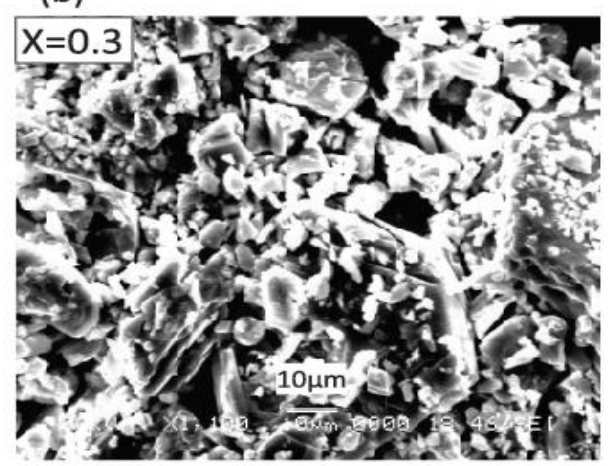

(d)

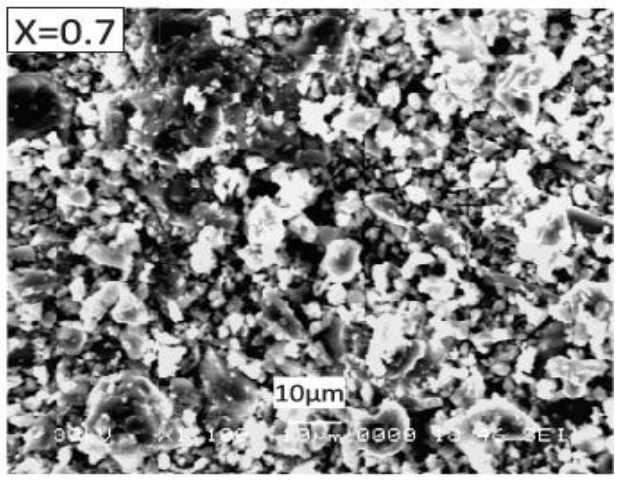
(e)

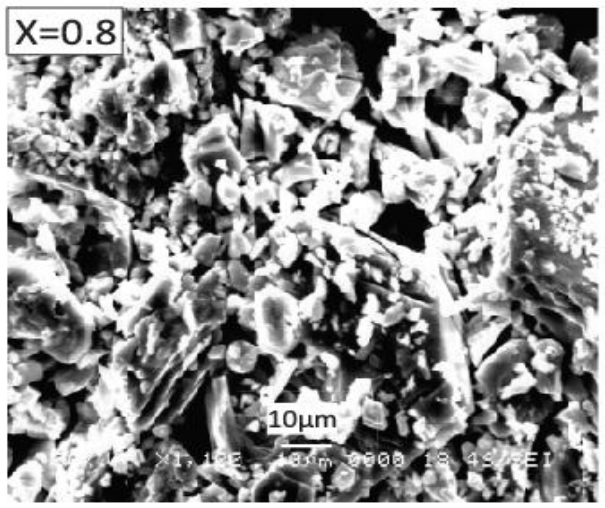

(f)

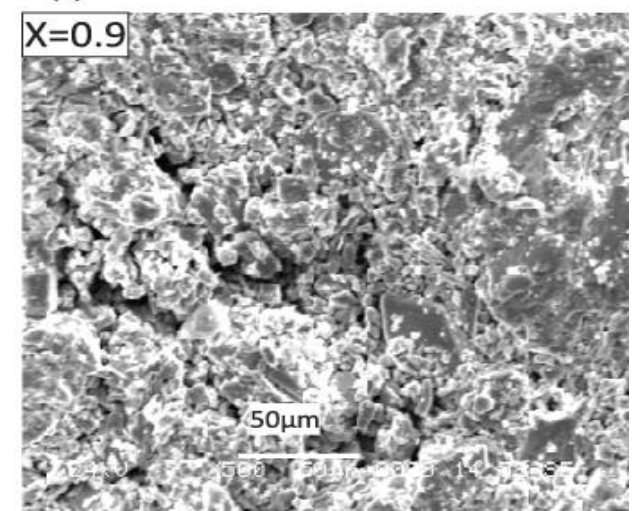

Fig.(3 a-f): SEM micrograph of the samples of $\mathrm{Ba}_{1-\mathrm{x}} \mathrm{Sr}_{\mathrm{x}} \mathrm{Fe}_{12} \mathrm{O}_{19}$.

The values of the Curie temperature were found to depend strongly on $\mathrm{Sr}^{2+}$ content (Table 2). From the data in the table one observed that positive and large $\theta$ values were obtained which assure the ferrimagnetic character of the nanoparticles. 
Figure (6a-f) shows the dc molar magnetic susceptibility $\left(\chi_{M}\right)$ as a function of the magnetic field strength against the absolute temperature. From the figure it is observed that the behavior of $\chi_{M}$ with temperature is the normal trend of ferrimagnetic materials from room temperature up to nearly the Curie point $\mathrm{T}_{\mathrm{C}}$. therefore one could tailor the magnetic properties of Ba-ferrite through $\mathrm{Sr}^{2+}$ doping at different levels according to the required application. Moreover the high Curie point $\mathrm{T}_{\mathrm{C}}$ of the investigated nanomaterials recommend to use of such substituted hexaferrite in high temperature applications.

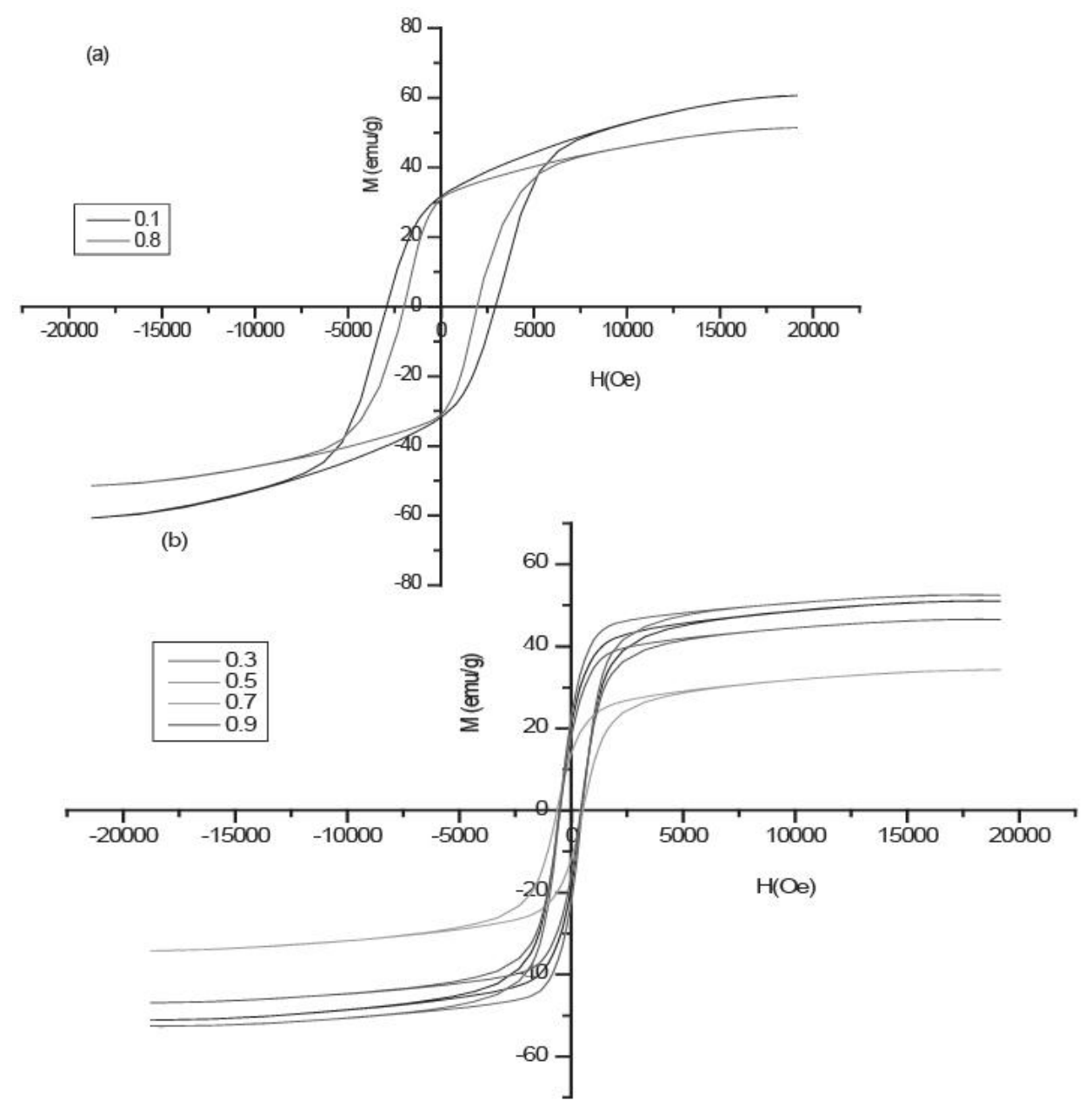

Fig.(4): Hysteresis loops of samples $\mathrm{Ba}_{1-\mathrm{x}} \mathrm{Sr}_{\mathrm{x}} \mathrm{Fe}_{12} \mathrm{O}_{19}$ at room temperature $\begin{array}{lll}\text { a) } x=0.1,0.8 & \text { b) } x=0.3,0.5,0.7,0.9\end{array}$ 

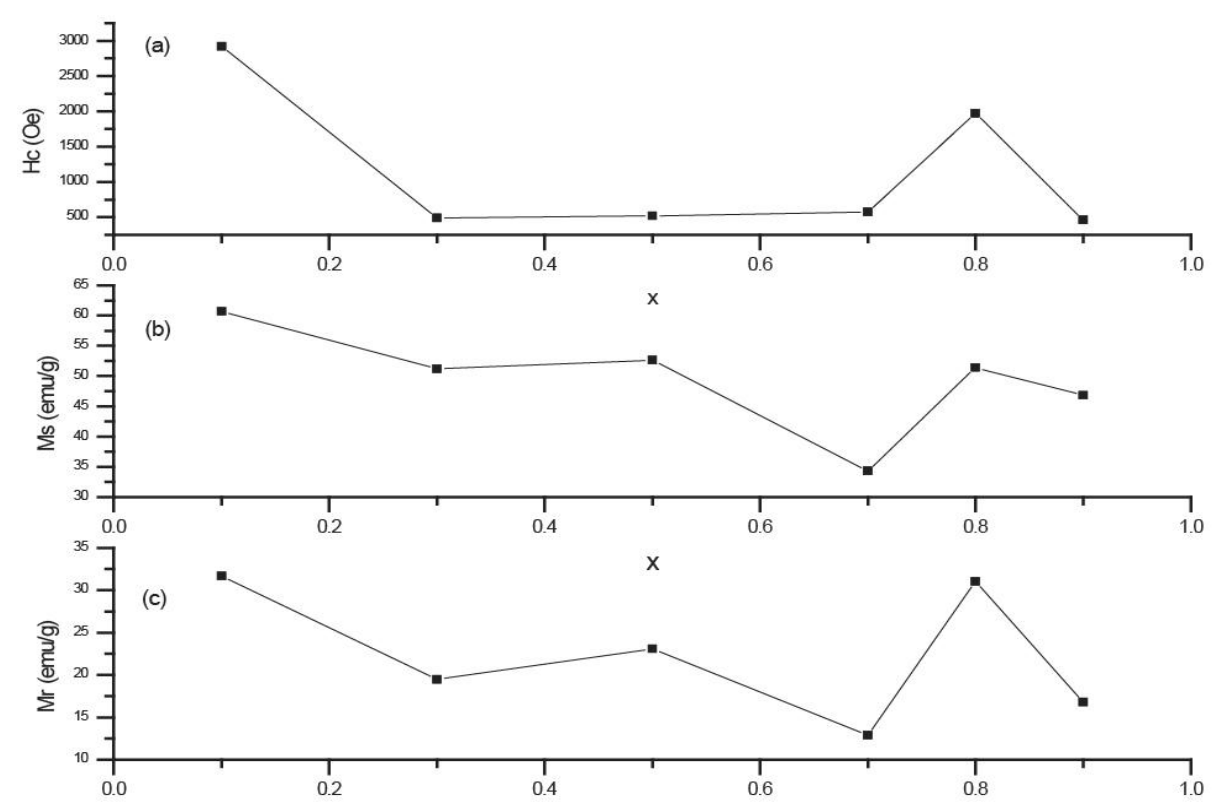

Fig.(5a-c): Values of $H_{c}, M_{s}$ and $M_{r}$ as a function of the concentration $x$.
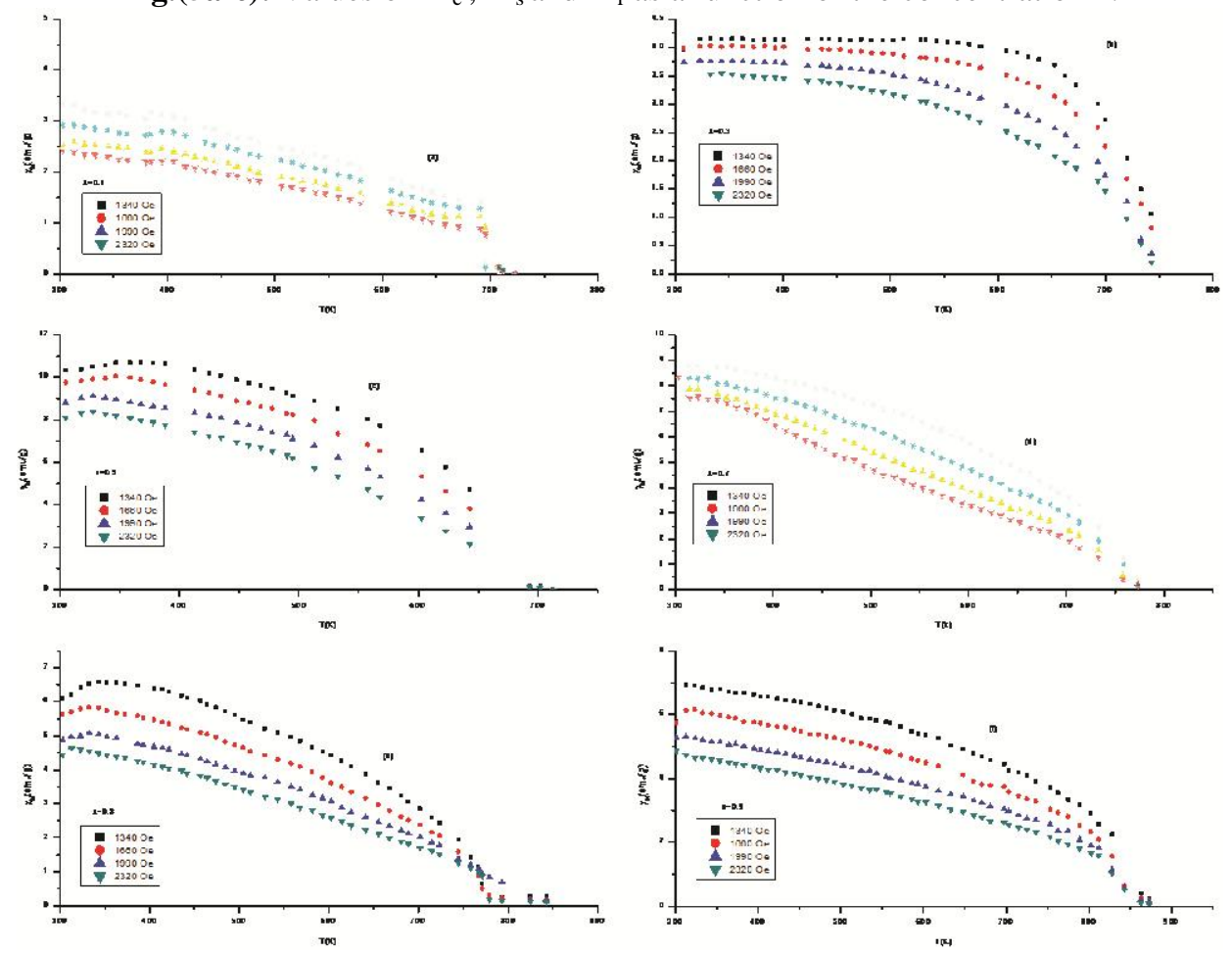

Fig.(6a-f): The molar susceptibility $\chi_{M}$ of samples $\mathrm{Ba}_{1-\mathrm{x}} \mathrm{Sr}_{x} \mathrm{Fe}_{12} \mathrm{O}_{19}$ as a function of absolute temperature $\mathrm{T}$. 


\section{Conclusion}

$\mathrm{Ba}_{1-\mathrm{x}} \mathrm{Sr}_{\mathrm{x}} \mathrm{Fe}_{12} \mathrm{O}_{19}(0.1 \leq \mathrm{x} \leq 0.9)$ nanoparticles were synthesized by citrate method. X-ray diffraction patterns reflects the existence of hexagonal structure in addition to non-magnetic secondary phase $\alpha-\mathrm{Fe}_{2} \mathrm{O}_{3}$ in all samples. The existence of the non-magnetic intermediate phase $\alpha-\mathrm{Fe}_{2} \mathrm{O}_{3}$ causes structural and chemical composition modifications. Substituting $\mathrm{Sr}^{2+}$ at the expense of $\mathrm{Ba}^{2+}$ at different levels make them suitable for different applications especially high temperature ones.

\section{Acknowledgement}

M. A. Ahmed ${ }^{\text {a }}$, A. M. EL - Refai ${ }^{\text {b }}$, S. M. Abd-Elwahab ${ }^{\text {a }}$

a) Materials Science Lab. (1), Physics Department, Faculty of Science Cairo University, Giza, Egypt,

The authors would like to acknowledge Dr. S. Eldek for great support and fruitful discussions.

\section{References}

1. R.F. Service, Small clusters hit the big time, Science, 271, 920 (1996).

2. K. Watanabe, J. Kawabe, Growth and characterization of Minute $\mathrm{BaFe}_{12-}$ ${ }_{2 x} \mathrm{Ti}_{\mathrm{x}} \mathrm{Co}_{\mathrm{x}} \mathrm{O}_{19}$ crystals from high-temperature solution, J. Mater. Chem. 7, 1797 (1997).

3. S. Wang, W.K. Ng, J. Ding, Preparation and characterization of $\mathrm{Al}$ doped longitudinal barium ferrite thin film media, Scr. Mater. 42, 861 (2000).

4. K.B.M. Paul, Magnetic and structural properties of Ba M-type ferriteComposite powders, Physcia B, 388, 337 (2007).

5. M.C. Dimri, S.C. Kashyap, D.C. Dube, Electrical and magnet properties of barium hexaferrite nanoparticles prepared by citrate precursor method, Ceramics International, 30, 1623 (2004).

6. K. Oda, T. Yoshio, K. Hirata, K. O-Oka, K. Takahashi, Preparation of barium ferrites from metal alkoxides, Journal of the Japan of Society of Powder and Powder Metallurgy, 29 (5), (1982).

7. S. Singhal, T. Namgyal, J. Singh, K. Chandra, S. Bansal, A comparative study on the magnetic properties of $\mathrm{MFe}_{12} \mathrm{O}_{19}$ and $\mathrm{MAlFe}_{11} \mathrm{O}_{19}(\mathrm{M}=\mathrm{Sr}, \mathrm{Ba}$ and $\mathrm{Pb}$ ) hexaferrites with different morphologies, Ceramics International, 37, 1833 (2011).

8. W. Roos, Formation of chemically coprecipitated barium ferrite, Journal of the American Ceramic Society, 63 (11), 601 (1980). 
9. D. Barb, L. Diamandescu, A. Rusi, D. Tarabasanu-Mihaila, M. Morariu, V.Teodorescu, Preparation of barium hexaferrite by hydrothermal method: structure and magnetic properties, Journal of Materials Science, 21, 1118 (1986).

10. M. Gadalla, H.W. Hennicke, Formation of barium hexaferrite, Journal of Magnetism and Magnetic Materials, 1 (2), 144 (1975).

11. M.H. Kim, D.S. Jung, Y.C. Kang, J.H. Choi, Nanosized barium ferrite powders prepared by spray pyrolysis from citric acid solution, Ceramics International, 35, 1933 (2009).

12. R.H. Arendt, The molten salt synthesis of single magnetic domain $\mathrm{BaFe}_{12} \mathrm{O}_{19}$ and $\mathrm{SrFe}_{12} \mathrm{O}_{19}$ crystals, Journal of Solid State Chemistry, 8, 339 (1973).

13. W.Onreabroy, K.Papato, G.Rujijanagul, K.Pengpat, T.Tunkasiri, Study of strontium ferrites substituted by lanthanum on the structural and magnetic properties, Ceramics International, 38S, S415 (2012).

14. G.Albanese, M.Carbucicchio, A.Deriu, Temperature dependence of the sublattice magnetizations in Al-and Ga-substituted M-type hexagonal ferrites, Physica Status Solidi, (a) 23, 351 (1974).

15. P.Sharma, R.A.Rocha, S.N.Medeiros, B.Hallouche, A.Paecsano Jr, Structural and magnetic studies on mechanosynthesized $\mathrm{BaFe}_{12-\mathrm{x}} \mathrm{MnxO}_{19}$, Journal of Magnetism and Magnetic Materials, 316, 29 (2007).

16. P.A.Marino-Castellanos, A.C.Moreno-Borges, G.Orozco-Melgar, J.A. Garcia, E.Govea-Alcaide, Structural and magnetic study of the $\mathrm{Ti}^{4+}$ - doped barium hexaferrite ceramic samples: theoretical and experimental results, Physica, B406, 3130 (2011).

17. A.Gonzalez-Angeles, J. Lipka, A.Gruskova, J.Slama, V.Jancarik, V. Slugen, Magnetic comparison of $\mathrm{BaCa}$ and $\mathrm{BaSr}$ substituted hexaferrite powders, Journal of Physics: Conference Series, 217, 1 (2010).

18. T.M.Meaz, C.B.Koch, $X$-raydiffraction and Mossbauer spectroscopic study of $\mathrm{BaCo}_{0.5 \mathrm{x}} \mathrm{Zn}_{0.5 \mathrm{x}} \mathrm{Ti}_{\mathrm{x}} \mathrm{Fe}_{12-2 \mathrm{x}} \mathrm{O}_{19}$ (M- type hexagonal ferrite) Egypt, Journal of Sol-Gel Science and Technology, 26, 197 (2003).

19. Vaishali V. Soman, V.M. Nanoti, D.K.Kulkarni, Dielectric and magnetic properties of $\mathrm{Mg}-\mathrm{Ti}$ substituted barium hexaferrite, Ceramics International, 39, 5713 (2013).

20. H. Kojima, Ferromagnetic Materials: A Handbook on the Properties of Magnetically Ordered Substances, North-Holland, Amsterdam, p.305 (1982).

21. C. Singh, S.B. Narang, I.S. Hudiara, Y. Bai, F. Tabatabaei, Static magnetic properties of $\mathrm{Co}$ and Ru substituted Ba-Sr ferrite, Mater. Res. Bull., 43, 176 (2008).

22. Muhammad Javed Iqbal, Saima Farooq, Extraordinary role of Ce-Ni elements on the electrical and magnetic properties of $\mathrm{Sr}$-Ba M-type hexaferrites, Materials Research Bulletin, 44, 2050 (2009). 
23. Neil J. Shirtcliffe, Simon Thompson, Eoin S. O'Keefe, Steve Appleton, Carole C. Perry, Highly aluminium doped barium and strontium ferrite nanoparticles prepared by citrate auto-combustion synthesis, Materials Research Bulletin, 42, 281 (2007).

24. Xian-song Liu, Lucia Fernandez-Garciab, Feng Hua, De-ru Zhua, Marta Suarez, Jose Luis Menendez, Magneto-optical Kerr spectra and magnetic properties of Co-substituted M-type strontium ferrites, Materials Chemistry and Physics, 133, 961 (2012).

25. Ping $\mathrm{Xu}$, Xijiang Han, Hongtao Zhao, Zhihua Liang, Jinfu Wang, Effect of stoichiometry on the phase formation and magnetic properties of $\mathrm{BaFe}_{12} \mathrm{O}_{19}$ nanoparticles by reverse micelle technique, Materials Letters, 62, 1305 (2008).

26. M.A. Ahmed, S.M. Ali, S.I. El-Dek, A Galal, Magnetite-hematite nanoparticles prepared by green methods for heavy metal ions removal from water, Materials Science and Engineering, B 178, 744 (2013).

27. Y. Liu, M.G.B. Drew, Y. Liu, J. Wang, M. Zhang, Preparation and magnetic properties of $\mathrm{La}-\mathrm{Mn}$ and $\mathrm{La}-\mathrm{Co}$ doped barium hexaferrites prepared via an improved co-precipitation/molten salt method, Journal of Magnetism and Magnetic Materials, 322, 3342 (2010).

28. Kalzmarek WA, Ninham BW, J. Appl. Phys. 1994; 76:6065.

29. Shin ind HS, Kwon S-J. In: Ferrites, proc ICF6, Tokyo and Kyoto; p. 1402 (1992).

30. Sudakar C, Subbanna GN, Kutty TRN., Wet chemical synthesis of multicomponent hexaferrites by gel-to-crystallite conversion and their magnetic properties., J. Magn. Magn. Mater, 263 (2003).

31. Surig C, Bonnenberg D, Hempel KA, Kerduck PK, Klaar HJ, Sauer C., J. Phys. IV, 7, C1 (1997).

32. Liu Y, Drew MGB, Wang J, Zhang M, Liu Y., Efficiency and purity control in the preparation of pure and/or aluminum-doped barium ferrites by hydrothermal methods using ferrous ions as reactants, J. Magn, Magn. Mater, 322 (2010).

33. Sankaranarayanan VKS, Pankhurst QA, Dickson DPE, Johnson CE., Ultrafine Particles of Barium Ferrite from a Citrate Precursor, J. Magn. Magn. Mater. 120, 73 (1993).

34. Kaczmarek WA, Calka A, Ninham BW., Mater, Chem, Phys., 32, 43 (1992).

35. Martirosyan KS, Galstyan E, Hossain SM, Wang Y-J, Litvinov D., Barium hexaferrite nanoparticles: synthesis and magnetic properties, Mater, Sci. Eng., B 176, 8 (2011).

36. C.R. Vestal, Q. Song, Z.J. Zhang, Effects of interparticle interactions upon the magnetic properties of $\mathrm{CoFe}_{2} \mathrm{O}_{4}$ and $\mathrm{MnFe}_{2} \mathrm{O}_{4}$ nanocrystals, Journal of Physical Chemistry, B 108, 18222 (2004). 